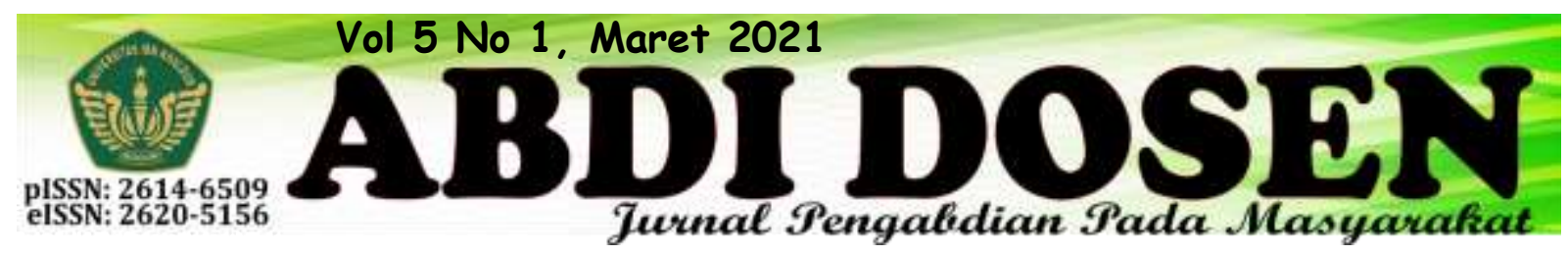

\title{
PENDAMPING ORANG TUA SISWA DALAM PEMBELAJARAN AGAMA ISLAM TERDAPAT HIKMAH DIBALIK COVID-19
}

\author{
Abdu Rahmat Rosyadi ${ }^{1}$, Syasya Wizman ${ }^{2}$ \\ rahmat@uika-bogor.ac.id ${ }^{1}$ \\ syasya.wizman1102@gmail.com ${ }^{2}$ \\ Pascasarjana Universitas Ibn Khaldun ${ }^{1}$, Mahasiswa KKN-GTM Universitas Ibn Khaldun tahun $2020^{2}$
}

\begin{abstract}
ABSTRAK
Hikmah di balik diadakannya pembelajaran agama islam jarak jauh, para orangtua bisa dengan penuh mendampingi anak-anaknya selama proses belajar. Hubungan orang tua dan anak akan berkembang dengan baik apabila kedua belah pihak saling memupuk keterbukaan. Penelitian ini bertujuan untuk membantu orang tua dalam menjaga terbukanya jalur komunikasi. Data penelitian dikumpulkan dengan mengunakan instrumen Wawancara, dan Survei . Hasil penelitian menunjukkan bahwa 1) Menjalin hubungan anak dengan orang tua semakin dekat ,2) Meningkatnya motivasi pembelajaran agama islam bagi manusia untuk mengembangkan kemampuan berfikir dalam mengolah potensi alam ini (Q.S.Al-Hasyr,21), 3) Memperoleh Hikmah dibalik masa pandemi.
\end{abstract}

Kata Kunci : Orang Tua Siswa, Pembelajaran Agama Islam, Hikmah.

\section{PENDAHULUAN}

\section{A. Latar Belakang Masalah}

Belajar tidak terjadi begitu saja. Apa yang kita pelajari, berapa banyak, seberapa cepat, dan seberapa bagus, sangat tergantung pada lingkungan. Montessori berpendapat bahwa lingkungan yang dipersiapkan untuk anak bisa merangsang, anak bereksplorasi dan berekspresi. Anak otomatis terdidik dalam minat belajar yang positif. Lagipula rasa ingin tahu tidak mengenal batas dan mencakup semua aspek kehidupan.

Komputer dan Televisi Kurikulum Montessori mempersiapkan anak menghadapi kehidupan. saat lahir, sistem sensorimotor diperlukan untuk mempertahan kelangsungan hidup. Area perkembangan ini dipacu dengan lingkungan prasekolah Montessori yang merangsang dan mendukung aktifitas spontan. Jadi anak mengoptimalkan kapasitas belajar yang tenomenal sekali dalam seumur hidup. Komputer dan televisi tidak disertakan dalam lingkungan prasekolah Montessori, meski anak sekarang mulai belajar teknologi sejak usia dini. meski animasi digital dan film dapat digunakan untuk tujuan pendidik ikan, namun hanya sebagai pengalaman penjembatan. Yakni sebagai realita semu yang tidak pernah bisa menggantikan pengalaman langsung di dunia nyata. Sebaliknya, lingkungan prasekolah Montessori menyediakan semua peluang mengembangkan kepekaan panca indra dan sistem urat syaraf setelah tiba masanya Pendekatan Montessori tidak menampil manfaat teknologi informasi dan media. Alat modern ini telah mengubah komunikasi dari segi jangkauan dan 
kecepatan. Bahkan telah menjembatani budaya dan kesenjangan sosial.

Sejalan dengan aspek perkembangan anak, menurut peraturan pemerintah RI Nomor 27 tahun 1990 tentang pendidikan prasekolah bahwa program kegiatan belajar anak usia dini meliputi aspek-aspek sebagai berikut: moral, agama, disiplin, kemampuan, berbahasa,daya pikir, daya cipta, emosi, kemampuan bermasyarakat, sosial, keterampilan jasmani. Kesepuluh aspek perkembangan di atas dalam implementasi nya dikelompokan menjadi dua, yaitu kelompok pengembangan dasar dan kelompok pengembangan kebiasaan.

Dalam Perspektif Pendidikan Islam Kurikulum adalah panduan dalam pelaksanaan pembelajaran untuk membentuk kepribadian anak kecil pada pendidikan prasekolah. Bagaimanapun kepribadian anak kecil juga dipengaruhi oleh faktor internal dan eksternal. bahwa:

Dijelaskan Sjarkawi

(2008:19)

(1) faktor internal mencakup faktor yang berasal dari dalam diri anak orang itu sendiri.

(2) faktor eksternal yaitu, faktor yang berasal dari luar diri orang itu sendiri.

Karakteristik Hubungan Anak Usia sekolah dengan Keluarga Masa usia sekolah dipandang sebagai masa untuk pertama kalinya anak memulai kehidupan sosial mereka yang sesungguhnya. Bersamaan dengan masuknya anak ke sekolah dasar, maka terjadilah perubah hubungan anak dengan orangtua. Perubahan tersebut di antaranya disebabkan adanya peningkatan penggunaan waktu yang dilewati anakanak bersama teman-teman sebayanya. Hubungan orangtua dan anak akan berkembang dengan baik apabila kedua pihak saling memupuk keterbukaan.
Berbicara dan mendengarkan merupakan hal yang sangat penting. Perkembangan yang dialami anak sama sekali bukan alasan untuk menghentikan kebiasaan di masa kecilnya. Hal ini justru akan membantu orangtua dalam menjaga terbukanya jalur komunikasi. Perubahan ini mempunyai dampak yang besar terhadap kualitas hubungan antara anak anak usia sekolah dan orangtua mereka (dalam Seifert \& Hoffnung 1994).

Pengaruh Agama Kehadiran agama dalam kehidupan masyarakat lebih melandasi lagi perkembangan pendidikan luar sekolah. Belajar membaca kitab suci, kaidah-kaidah agama, tata cara sembahyang. yang pada umumnya dilakukan di tempat-tempat peribadatan, merupakan kegiatan belajar- mengajar yang mendasari situasi pendidikan luar sekolah. Dalam perkembangan selanjutnya, agama memberikan motivasi kepada masyarakat bahwa belajar itu merupakan kewajiban setiap pemeluk agama, dan kegiatan belajar dilakukan di dalam dan terhadap lingkungan kehidupannya. Sebagai ilustrasi, Agama Islam memberikan aorongan kuat agar pemeluknya senantiasa belajar. Belajar ialah Kewajiban yang ditetapkan oleh Allah untuk dilakukan oleh setiap orang Syarat utama yang perlu dimiliki oleh setiap individu untuk melakukan Kegiatan belajar adalah kemampuan membaca. Oleh sebab itulah, wahyu pertama yang diturunkan Allah kepada Rasul-Nya, untuk disampaikan Repada manusia, adalah perintah untuk membaca. "Bacalah dengan ana 7uhanmu yang telah menjadikan" (2.5. Al- Alaq, ayat 1)

Kewajiban umat untuk belajar ini dipertegas oleh Rasulullah SAW dalam haditsnya: "Menuntut ilmu adalah wajib bagi setiap Muslim pria dan wanita" 
(Tholabul ilmifaridlotun ala kulli muslimin wa muslimatin) "Tuntutlah ilmu sejak dalam buaian sampai masuk ke liang kubur (Uthlubul ilma minal mahdi ilallahdi). Secara singkat dapat difahami bahwa belajar adalah kewajiban yang harus dilakukan oleh setiap umat Islam selama hidupnya. Menurut agama, belajar adalah kunci utama untuk mencapai kemajuan dan kebahagiaan. Belajar, dalam pengertian ini, adalah proses pencarian dan penguasaan ilmu untuk diterapkan dalam kehidupan. Hadits Nabi menjelaskan: "Barangsiapa ingin memperoleh kebahagiaan di dunia maka ia harus menguasai ilmu, barangsiapa ingin meraih kebahagiaan di akhirat maka ia harus menguasai ilmu, dan barangsiapa ingin mendapatkan kebahagiaan keduarya maka ia harus menguasai ilmu" (Man arooda dunya fa'alaiha bil'ilmi, man aroodal aakhirota fa'alaiha bil'ilmi, wa man arooda humaafa'alaiha bil'ilmi).

Motivasi agama, bagi manusia, untuk mengembangkan kemampuan berfikir dalam mengolah potensi alam ini, telah ditegaskan oleh Allah SWT "Dan Dia (Allah) menundukkan untukmu segala sesuatu yang ada di iangit dan di bumi semuanya, (sebagai suatu rahmat) dari pada-Nya. Sesungguhnya padayang demikian itu benar-benar terdapat tandatanda kekuasaan Allah bagi orang-orang yang berpikir" (Q. S. Al-Jatsiyah, 14). 2" Dan berbagai perumpamaan itu Kami buat untuk manusia supaya mereka berpikir" (Q. S. Al-Hayyr, 21).

Kebutuhan belajar yang dirasakan pada tahun lalu mungkin berbeda dengan yang dirasakan pada tahun ini dan mungkin akan berbeda pula dengan kebutuhan belajar yang akan dirasakan pada tahun mendatang.
Lebih jauh Johnson menjelaskan bahwa dalam kelompok beiajar terdapat tiga macam interaksi yaitu: interaksi antara sumber belajar dengan warga belajar, interaksi antara warga belajar dengan program belajar, dan interaksi antar warga belajar. Namun bagaimana pun beragamnya bentuk kelompok dan proses belajar tetapi suatu hal yang mendasari kelompok belajar ialah adanya kebutuhan belajar.

Pemerintah menerapkan kebijakan yaitu Work From Home (WFH). Kebijakan ini merupakan upaya yang diterapkan kepada masyarakat agar dapat menyelesaikan segala pekerjaan di rumah. Pendidikan di Indonesia pun menjadi salah satu bidang yang terdampak akibat adanya pandemi covid-19 tersebut. Dengan adanya pembatasan interaksi, Kementerian Pendidikan di Indonesia juga mengeluarkan kebijakan yaitu dengan meliburkan sekolah dan mengganti proses Kegiatan Belajar Mengajar (KBM) dengan menggunakan sistem dalam jaringan (daring). Dengan menggunakan sistem pembelajaran secara daring ini, terkadang muncul berbagai masalah yang dihadapi oleh siswa dan guru, seperti materi pelajaran yang belum selesai disampaikan oleh guru kemudian guru mengganti dengan tugas lainnya. Hal tersebut menjadi keluhan bagi siswa karena tugas yang diberikan oleh guru lebih banyak.

\section{B. Rumusan Masalah}

1. Memahami tujuan dan Manfaat

2. Memahami alur kerja dalam penelitian

3. Mengidentifikasi Bagaimana Langkah-Langkah dalam 


\section{Tujuan Penelitian}

1. Untuk membantu meningkatkan sistem pelayanan.

2. Tujuan operasional dari penelitian ini adalah untuk mengetahui kendala-kendala apa saja yang ada pada sistem survei yang sedang berjalan saat ini.

3. Tujuan Fungsional dari penelitian ini yaitu agar hasil dari penelitian dapat dimanfaatkan dan digunakan.

\section{Urgensi Penelitian}

Salah satu hikmah di balik pandemi Covid-19 adalah timbulnya kedekatan antara orang tua dengan anak. Sebelumnya, orang tua dan anak hanya ketemu sebentar di pagi hari dan di malam hari serta saat hari libur. Selama masa pandemi, bisa dikatakan setiap hari dan sepanjang hari, orang tua dan anak selalu bersama..

\section{E. Manfaat Penelitian}

Konsep pembelajaran Pendidikan dari rumah yang diselenggarakan oleh

\section{METODE PENELITIAN}

Pengabdian kepada masyarakat diakukan dengan pendekatan studi kasus terhadap fenomena social yang terjadi di masyarakat. Obyek pengabdian adalah proses pembelajaran agama yang dilaksanakan penelitian ini dilaksanakandi sekolah Bersama guru secara offline. Namun, pada masa pandemic covid-19 ini proses pembelajaran dialihkan kerumah yang dilakukan oleh siswa Bersama orangtua secara online melalui media daring dan luring, atau media lainnya.

Pengabdian kepada masyarakat dilaksanakan selama 20 hari dari tanggal 25 agustus 2020 sampai dengan 15 pemerintahan di daerah beserta perangkatnya dan para pelaku Pendidikan pada masa pandemic covid-19 akan bermanfaat pada masa pandemic covid-19 dan jangka Panjang sebagai berikut:

1. Pemerintah di daerah khususnya di kelurahan Bersama perangkat kelurahan sampai RW/RT dapat memastikan dan memetakan sarana dan prasarana Pendidikan yang ada diwilayahnya antara lain ketersediaan pulsa, sinyal, dan alat belajar semisal HP, Laptop,atau computer bagi masyarakat;

2. Lembaga Pendidikan yang berada dilingkungan Kemendikbud atau Kemenag dapat memfasilitasi guru-guru dalam melaksanakan pemebelajaran dari rumah melalui media social, zoom, Instagram, facebook, youtube;

3. Pelaku pembelajaran dari rumah dengan menggunakan teknologi informasi sebagai media belajar tatap muka secara offline ke media belajar secara online.

september 2020 dengan lokasi di wilayah provinsi Jawa Barat.

Kel. Kota Bogor - Kedung Waringin Kec. Tanah Sareal. Subjek penelitian untuk studi kualitatif adalah para orang tua siswa yang berada dilingkup rumah lokasi penelitian yang ditetapkan 3 orang tua siswa dasar target. Berdasarkan konsep ini, jumlah orang tua siswa yang dilibatkan dalam penelitian adalah 3 orang tua siswa. Untuk kelas uji eksperimen luas dipilih siswa (1)kelas $1 \mathrm{SD}$, (2) kelas 2 SMP dan (3) kelas 1 SMA berasal dari 3 kategori sekolah dari 1 kab. wilayah sampel. Penentuan lokasi rumah dilakukan secara 
purposife dengan pertimbangan lokasi rumah dan kemampuan akademis siswa dan orang tua.

Instrumen yang digunakan untuk mengumpulkan data penelitian ini adalah analisis data dilakukan secara kualitatif berkitan dengan (1) pedoman wawancara semi struktur untuk mengumpulkan data

\section{HASIL PENELITIAN}

Wawancara dan Survei sebagai cara dalam pengumpulan data yang kami lakukan menjadi tahap akhir dalam penelitian ini. Setelah itu Peneliti mengajukan 2 pernyataan kesan dan pesan respons orang tua tentang model (2) catatan lapangan untuk mengumpulkan data hasil kegiatan survei , dan (3) dokumentasi untuk mengumpulkan data proses pelaksaan penelitian. Berdasarkan jenis instrumen yang digunakan, penelitian ini menghasilkan dua jenis data yakni data kualitatif yang diolah secara kualitatif.

dalam bentuk wawancara yang berkaitan dengan pendapat mereka tentang hikmah pembelajaran agama islam dibalik covid19.

DATA ORANG TUA SISWA

\begin{tabular}{|c|c|c|c|c|}
\hline Kategori & Kelas & Nama Orang Tua Siswa & Nama & Nama Sekolah \\
\hline SD & I & Henny Siswati & Ghaneswara & $\begin{array}{c}\text { SD Islam Terpadu } \\
\text { Al-Makmur }\end{array}$ \\
\hline SMP & VIII & Rusviani & Velania & SMP At-Taufik \\
\hline SMK & X & Dwi Juliati Anggraini & Alya Nur Jahirah & SMK Negeri 1 \\
\hline GURU & IX & - & Usth. Sari Safitri & SMP At-Taufik \\
\hline
\end{tabular}

HASIL WAWANCARA

\begin{tabular}{|c|c|c|c|}
\hline \multicolumn{2}{|c|}{$\begin{array}{c}\text { Responden ke } \\
-\end{array}$} & \multirow[t]{2}{*}{ Kesan } & \multirow[t]{2}{*}{ Pesan } \\
\hline No. & Kategori & & \\
\hline 1 & SD & $\begin{array}{l}\text { Saya sebagai wali orang tua nya yaitu } \\
\text { omanya / neneknya dikarenakan kedua } \\
\text { orang tuanya bekerja sayalah yang } \\
\text { mengawasi, memantau sekaligus } \\
\text { mengajarkan kepada cucu saya } \\
\text { Pembelajaran Agama Islam disetiap } \\
\text { harinya yang berlangsung di sekolah. } \\
\text { Saya banyak mendapat kendala masa } \\
\text { covid-19 ini dikarenakan cucu saya } \\
\text { belum merasakan sekolah di bangku } \\
\text { SD dan saya sudah di usia } 64 \text { tahun } \\
\text { alhamdulillah saja untuk masalah }\end{array}$ & $\begin{array}{l}\text { Karena faktor umur saya } \\
\text { yang suka darah tinggi } \\
\text { karena anak-anak kecil sulit } \\
\text { diatur dan manja sama } \\
\text { omanya sulit mematuhi } \\
\text { aturan yang saya berikan. } \\
\text { Setiap do'a yang saya } \\
\text { panjatkan mudah -mudahan } \\
\text { pandemic segera berakhir } \\
\text {,dan kegiatan rutinitas anak- } \\
\text { anak kembali normal karena } \\
\text { saya dan anak-anak terlalu }\end{array}$ \\
\hline
\end{tabular}




\begin{tabular}{|c|c|c|c|}
\hline & & $\begin{array}{l}\text { gadget saya sedikitnya faham karena } \\
\text { saya harus lebih ekstra menjaga dan } \\
\text { mendidiknya dirumah. Dengan masalah } \\
\text { covid-19 yang terjadi saat ini } \\
\text { membuatnya aneh dan sulit untuk } \\
\text { mengerjakan dan menerima kegiatan } \\
\text { sekolah di setia pagi nya, seperti : } \\
\text { (a) Mengajaknya memakai seragam } \\
\text { sekolah dirumah } \\
\text { (b) Menuntun dan mengajarkan } \\
\text { shalat dhuha } \\
\text { (c) membimbing hapalan surat } \\
\text { pendek karena belum banyak } \\
\text { dia dapatkan hapalan pada masa } \\
\text { dia di TK. } \\
\text { Hikmah dibalik masa saat ini dengan } \\
\text { kegiatan saya saat ini insyaallah saya } \\
\text { dijauhkan dari penyakit Alzeimer } \\
\text { (pikun/lupa) dikarena kan saya juga } \\
\text { harus ikut belajar menghapalkan surat } \\
\text { dan pelajaran disekolah agar saya bis } \\
\text { mengajarkan kepada cucu saya. }\end{array}$ & $\begin{array}{l}\text { jenuh dengan rutinitas saat } \\
\text { ini, lebih baik semua } \\
\text { dikerjakan disekolah ketemu } \\
\text { guru dan teman sebayanya. } \\
\text { Dikarena kan cucu saya sulit } \\
\text { menerima pembelajaran } \\
\text { dengan cepat secara online } \\
\text { seperti ini dia lebih cepat } \\
\text { menerima pembelajaran } \\
\text { langsung tatap muka dengan } \\
\text { gurunya. Solusi agar dia } \\
\text { dapat melaksanakan } \\
\text { pembelajaran yang diberikan } \\
\text { dengan terpaksa harus } \\
\text { menggunakan ustad / guru } \\
\text { yang berada didekat rumah } \\
\text { ini. }\end{array}$ \\
\hline 2 & SMP & $\begin{array}{l}\text { Selama pandemic ini lebih banyak dan } \\
\text { aman belajar dirumah kalua bertatap } \\
\text { muka disekolah ya resikonya tinggi . } \\
\text { Dalam pembelajaran agama islam } \\
\text { disekolah ini ada berbagai macam } \\
\text { kegiatan islami diluar kelas, seperti : } \\
\text { - Qira'at } \\
\text { - Muthaba'ah } \\
\text { - Dan Amalan harian seperti : } \\
\text { Shalat fardhu,sunah,dan puasa } \\
\text { Dan dalam waktu seminggu } \\
\text { sekali saya harus melaporkan } \\
\text { kepihak sekolah dari pantauan } \\
\text { saya dengan kegiatan tersebut } \\
\text { yg dilaksanakan dirumah. } \\
\text { Hikmahnya jadi lebih dekat dengan } \\
\text { orang tua ,dan orang tua bisa lebih } \\
\text { banyak mantau kegiatannya selama } \\
\text { mendampingi dia sekolah dan ditambah } \\
\text { lagi saya pun ikut mengulang pelajaran } \\
\text { lagi karena jika ada tugas yg dia kurang } \\
\text { paham dengan penjelasan gurunya }\end{array}$ & $\begin{array}{l}\text { Harapan saya mungkin sama } \\
\text { seperti para orang tua } \\
\text { lainnya ,berharap pandemic } \\
\text { ini cepat selesai dan anak- } \\
\text { anak bisa bertatap muka } \\
\text { langsung dengan guru dan } \\
\text { berjumpa lagi dengan teman } \\
\text { sebayanya. }\end{array}$ \\
\hline
\end{tabular}




\begin{tabular}{|c|c|c|c|}
\hline & & $\begin{array}{l}\text { berikan dia akan tanyakan langsung ke } \\
\text { saya. Karena terkadang lewat daring } \\
\text { seperti sekarang ini anak sulit bertanya } \\
\text { bisa dibilang seperti keterbatasan waktu } \\
\text { untuk bertanya dan memahami } \\
\text { pelajaran yang diberikan, }\end{array}$ & \\
\hline 3 & SMK & $\begin{array}{l}\text { Alhamdulillah saya tidak terlalu banyak } \\
\text { mendapatkan kendala tapi Hikmahnya } \\
\text { saya sebagai orang tua dapat lebih } \\
\text { sering lagi mengawasi anak di kegiatan } \\
\text { ibadahnya begitu pun masuk kelas } \\
\text { kemudian memantau sudah atau belum } \\
\text { mengerjakan tugasnya, hanya sebatas } \\
\text { itu saja. sejauh yang saya liat selama } \\
\text { Pembelajaran Agama Islam } \\
\text { berlangsung guru ketemu anak-anak } \\
\text { melalui google meet, memberikan } \\
\text { materi lalu mendengarkan kemudian } \\
\text { diberikan tugas, karena sudah remaja } \\
\text { dan mandiri anak saya mencari bahan } \\
\text { jawaban sendiri dan mengirimkannya } \\
\text { melalui whatsapp atau classroom. }\end{array}$ & $\begin{array}{l}\text { Walapun tidak mendapatkan } \\
\text { kendala dalam memantau } \\
\text { anak-anak tapi saya Berharap } \\
\text { pandemi ini cepat berakhir } \\
\text { sehingga anak-anak bisa } \\
\text { langsung sekolah masuk } \\
\text { seperti biasa, dan pesan } \\
\text { untuk anak saya sih masih } \\
\text { tetep semangat buat belajar } \\
\text { meskipun dirumah tetep } \\
\text { pakai baju seragam agar saat } \\
\text { belajar masih tetep } \\
\text { semangat. }\end{array}$ \\
\hline 4 & GURU & $\begin{array}{l}\text { Pembelajaran disekolah ini tidak hanya } \\
\text { pembelajaran yang diberikan dari dinas } \\
\text { pembelajaran disini berupa: } \\
\text { - Qira'at } \\
\text { - Shalat dhuha } \\
\text { - Dzikir pagi dan petang } \\
\text { - Shalat berjama'ah (terkadang } \\
\text { yang menjadi imam siswa } \\
\text { disini) } \\
\text { Tapi semua pembelajaran yang tadi } \\
\text { terkendala maka dari itu disiasati } \\
\text { dengan form mutaba'ah yang harus di } \\
\text { ceklis sama anak2 di setiap harinya } \\
\text { selama dirumah, dan juga untuk } \\
\text { mutaba'ahnya atau setor hapalannya } \\
\text { kami siasati dengan google classroom } \\
\text { dan juga di E-Learning,dan fungsi e- } \\
\text { learning dibuat agar mempermudah } \\
\text { guru menyampaikan materi melalui } \\
\text { power point yang diberikan dan } \\
\text { memberi menilai kepada siswa }\end{array}$ & $\begin{array}{l}\text { Kebijakan pemerintah jangan } \\
\text { terlalu fokus hanya dengan } \\
\text { pendidikan tapi dengan } \\
\text { ketenaga kerjaan dan lainnya } \\
\text { karena itu semua jadi satu } \\
\text { kesatuan dalam pendidikan, } \\
\text { begitupun dengan KD yang } \\
\text { diturunkan membuat anak } \\
\text { jadi terbatas menerima } \\
\text { pembelajaran yang diberikan } \\
\text { yang berdampak pada } \\
\text { potensi anak-anak tidak } \\
\text { berkembang optimal } \\
\text { seperti,misalnya: anak kelas } \\
3 \text { smp sudah bisa mencapai } \\
90 \% \text { tapi dengan pjj ini anak } \\
\text { hanya bisa mencapai } 45 \% \\
\text { dari ketentuan pemerintah } \\
\text { buat banyak potensi anak } \\
\text { tidak tersalurkan dan beralih } \\
\text { ke kegiatan yang lalai }\end{array}$ \\
\hline
\end{tabular}




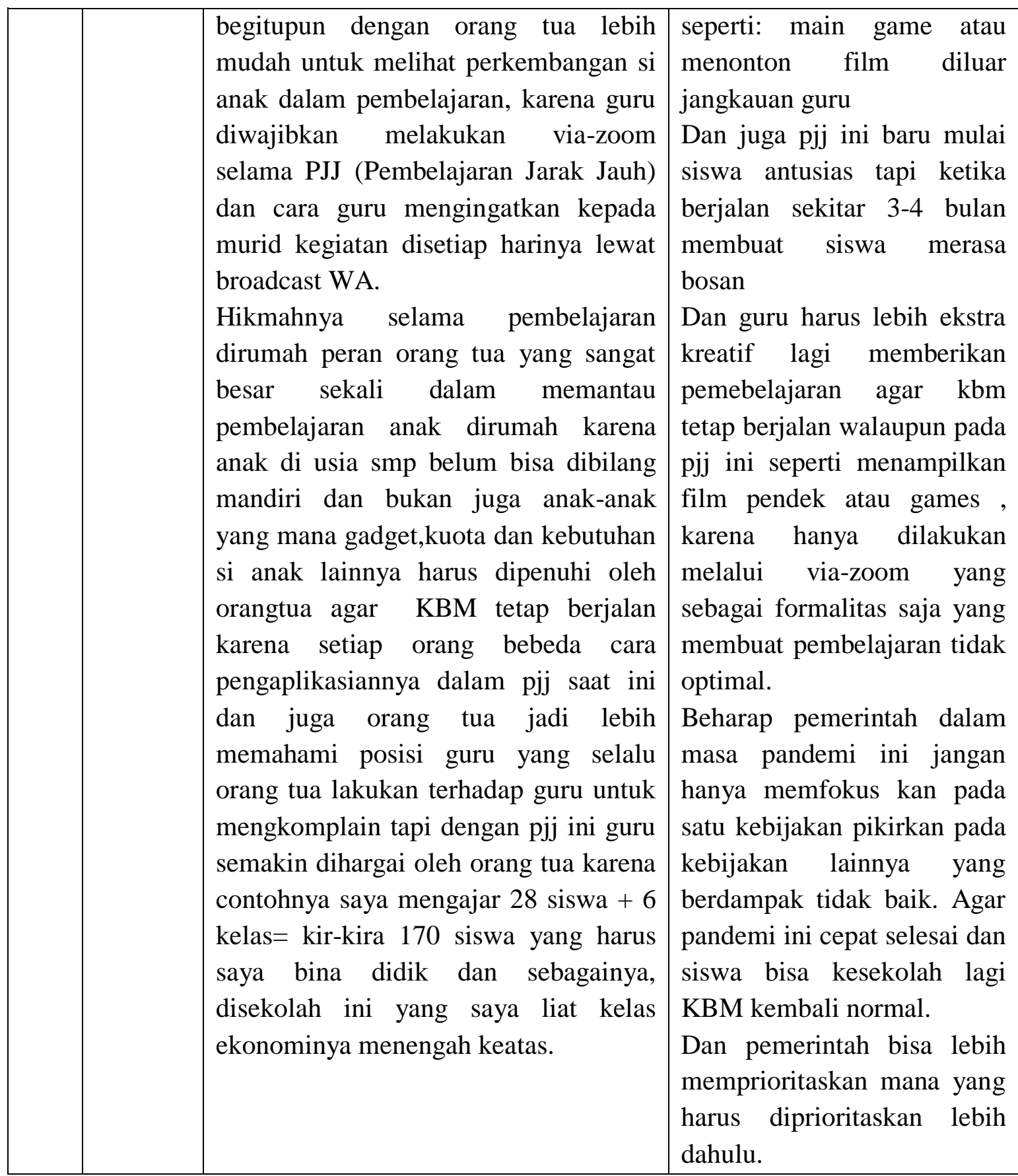

Setelah memberikan pernyataan pada wawancara, di tahap ke-2 yaitu tahap terakhir dalam pengumpulan data penelitian ini kami melakukan survei, karena dengan teknik ini kami dapat melakukan pengambilan data secara relevan. Kami bisa mengamati kondisi interaksi siswa dalam pembelajaran. 

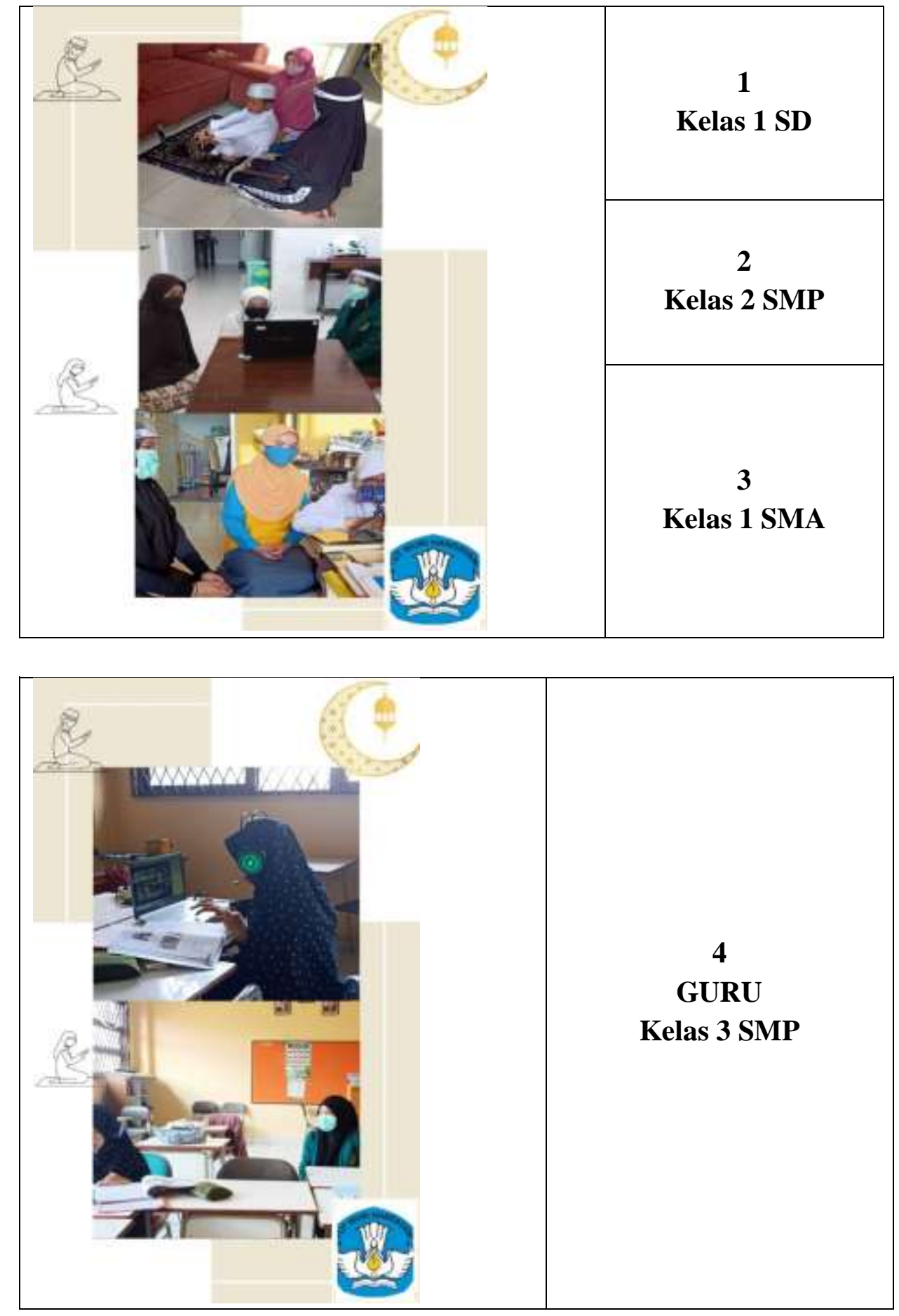


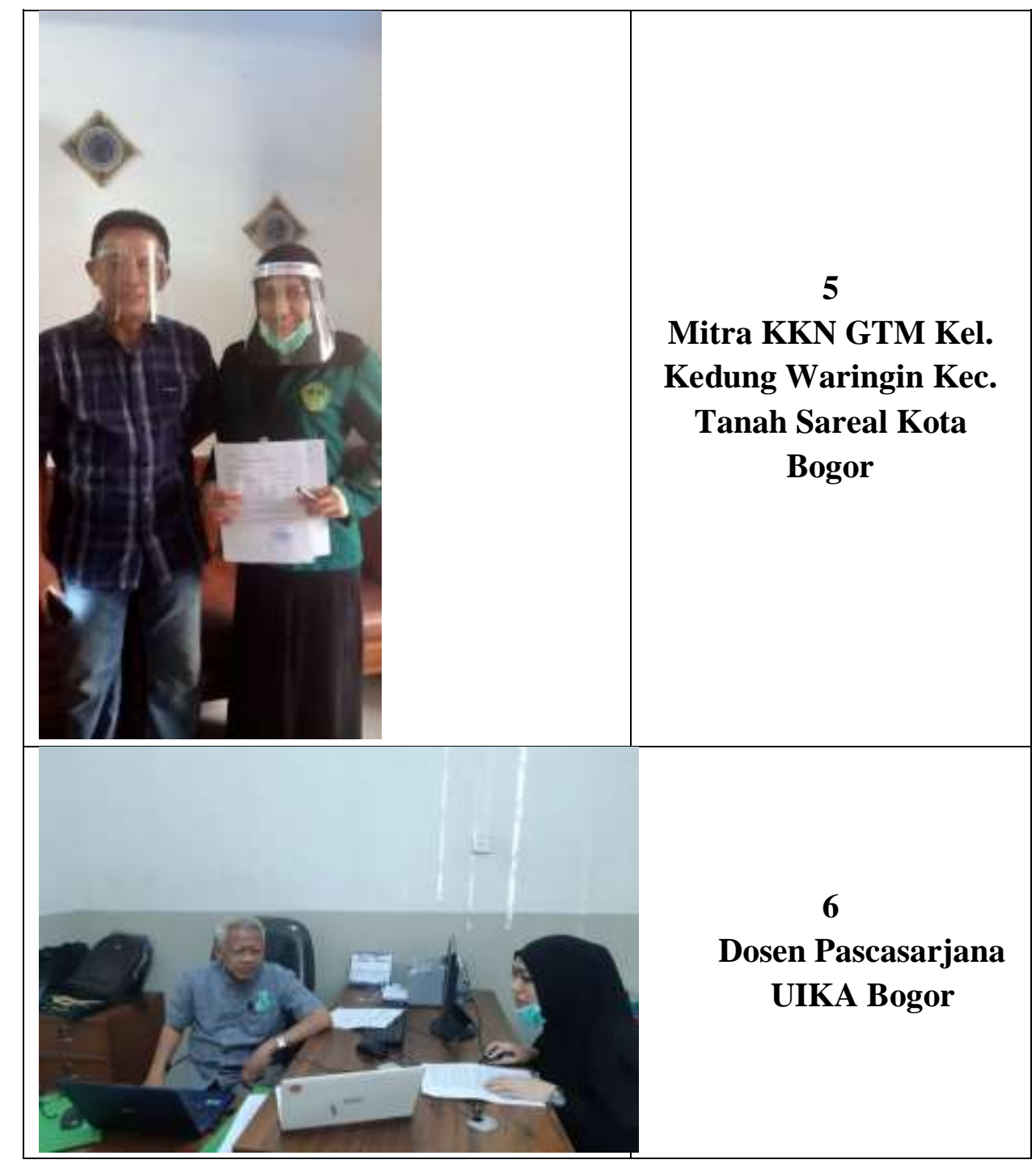

\section{PEMBAHASAN}

Secara umum perkembangan peserta didik dapat dikelompokkan ke dalam tiga aspek perkembangan, yaitu perkembangan fisik, kognitif, dan psikososial.

Karakteristik Anak Usia Sekolah Dasar (SD) usia rata-rata anak Indonesia saat masuk sekolah dasar adalah 6 tahun dan selesai pada usia 12 tahun. Kalau mengacu pada pembagian tahapan perkembangan anak, berarti anak usia sekolah berada dalam dua masa perkembangan anak, yaitu masa kanakkanak tengah(6-9 tahun), dan masa kanakkanak akhir (10-12 tahun).

Karakteristik Anak Usia Sekolah Menengah (SMP) Dilihat dari tahapan perkembangan yang disetujui oleh banyak ahli, anak usia sekolah menengah (SMP) berada pada tahap perkembangan puber tas (10-14 tahun). Terdapat sejumlah karakteristik yang menonjol pada anak usia SMP.

Karakteristik Anak Usia Sekolah Menengah (SMP) Dilihat dari tahapan perkembangan yang disetujui oleh banyak ahli, anak usia sekolah menengah (SMP) berada pada tahap perkembangan puber tas (10-14 tahun). Terdapat sejumlah karakteristik yang menonjol pada anak usia SMP

Dalam pembahasan dari hasil wawancara tersebut terdapat beberapa 
kesimpulan dari setiap point yang dinyatakan yaitu sebagai berikut:

Hasil dari wawancara pernyataan ke1 , wali orang tua nya yaitu omanya / neneknya menurut oma henny menunjukan bahwa mengawasi, memantau sekaligus mengajarkan kepada cucu saya Pembelajaran Agama Islam disetiap harinya yang berlangsung di sekolah selama daring atau online. Hikmah dibalik masa saat ini dengan kegiatan oma henny saat ini insyaallah dijauhkan dari penyakit Alzeimer (pikun/lupa) dikarenakan harus ikut belajar menghapalkan surat dan pelajaran disekolah agar bisa mengajarkan kepada cucunya.

Di karena kan usia cucunya saat ini harus lebih ekstra diawasi, diajarkan, dan dibimbing selama PJJ saat ini agar KBM tetap berjalan.

Hasil dari wawancara pernyataan yang ke-2, Bu Rusviani Hikmahnya jadi lebih dekat dengan orang tua ,dan orang tua bisa lebih banyak mantau kegiatannya selama mendampingi dia sekolah dan ditambah lagi harus ikut serta ketika KBM berlangsung yang seperti:

-mengulang pelajaran

-jika ada tugas yg dia kurang paham

-begitupun dengan penjelasan gurunya berikan pasti dia akan tanyakan langsung ke orangtuanya.

Karena diusianya sekarang belum dibisa dibilang mandiri dan juga bukan anak-anak yang masih sangat membutuhkan pengawasan dan bimbingan orangtua.
Hasil dari wawancara pada pernyataan ke-3 , Bu Dwi tidak terlalu banyak mendapatkan kendala tapi Hikmahnya sebagai orang tua dapat lebih sering lagi mengawasi anak di kegiatan ibadahnya begitu pun masuk kelas kemudian memantau sudah atau belum mengerjakan tugasnya, hanya sebatas itu saja karena diusianya sudah bisa mandiri untuk mengerjakan tugas dan menjalankan KBM .

Beberapa responden memilih untuk melakukan PJJ dalam pembelajaran berlangsung dengan menggunakan google, e-leaning, classroom, classmeet dari broadcast WA, dan bertanya kepada orang tua yang walaupun siswa hanya mengetahui $45 \%$ selama KBM berjalan dimasa pandemi ini.

Begitupun dengan pernyataan ke-4 guru, hikmahnya dengan pjj ini guru semakin dihargai oleh orang tua.

Hasil dari data wawancara diatas menjelaskan bahwa orangtua siswa merasa bosan dan kesulitan dalam mengerjakan, mengajarkan dan membimbing anaknya begitu pun dengan guru yang diharuskan juga lebih ekstra lagi membuat siswanya tidak bosan dalam pemebelajaran yang diberikan. Hikmahnya adalah adanya saling menghargai antara guru dan orangtua , begitupun memahami dan pendekatan antara siswa dan orangtua

Dari hasil survei dapat dilihat bahwa orangtua siswa menjadi peran paling penting terhadap pjj yang dilakukan agar kbm tetap berjalan selama masa covid-19. 


\section{KESIMPULAN}

Adanya kebijakan pemerintah untuk melakukan pembelajaran jarak jauh melalui online, maka dapat memberikan manfaat yaitu meningkatkan kesadaran untuk menguasai kemajuan teknologi saat ini dan mengatasi permasalahan proses pendidikan di Indonesia. Hikmah penggunaan media seperti handphone atau gadget, dapat dikontrol untuk kebutuhan belajar anak. Peran orang tua semakin diperlukan dalam melakukan pengawasan terhadap penggunaan gadget.

Hal tersebut memberikan dampak yang positif bagi anak, dalam

\section{DAFTAR PUSTAKA}

Bahruddin, E., Rosyadi, A. R., and Edy, E. 2018. Persepsi Siswa Madrasah Tsanawiyah Terhadap Pendidikan Multikultural Keagamaan Dalam Penanggulangan Radikalisme Secara Dini. Edukasi Islami: Jurnal Pendidikan Islam, 7(02), pp.179-194.

Dra. Desmita, M.Si. Cetakan kelima, 2014. Psikologi Perkembangan Peserta Didik. Bandung

Elizabeth G. Hainstock - Lee Havis (Direktur Eksekutif, Lembaga Montessori Internasional. 2008. KENAPA MONTESSORI? Keunggulan Metode Montessori bagi Tumbuh Kembang Anak. Hak cipta : Mitra Media memanfaatkan teknologi untuk hal-hal yang bermanfaat. Anak cenderung akan menggunakan handphone untuk mengakses berbagai sumber pembelajaran dari tugas yang diberikan oleh guru. Sehingga akan membuat anak menghindari penggunaan gadget pada hal-hal kurang bermanfaat atau negatif. Walaupun pendidikan di Indonesia ikut terdampak adanya pandemi covid-19 ini, namun dibalik semua itu terdapat hikmah dan pelajaran yang dapat diambil.

Prof. Dr.Syafaruddin, M.Pd - Herdianto, MA - Hj. Ernawati, MA , 2011. PENDIDIKAN PRASEKOLAH: Perspektif Pendidikan Islam \& Umum. Medan

Rosyadi, A. R. (2018). Konsep dan Sistem Pendidikan Islam. Ta'dibuna: Jurnal Pendidikan Islam 1 (1). DOI: http://dx.doi.org/10.32832/tadibuna. $\underline{v 1 i 1.436}$

Sudjana S., H. Djudju, Prof.; SPd., M.Ed., PhD. Cetakan ketiga $1442 \mathrm{H}-2001$ M. Pendidikan Luar Sekolah :Wawasan, Sejarah Perkembangan, Falsafah \& Teori Pendukung serta Asas. Bandung 